\title{
Pack Density Limitations of Hybrid Parachutes
}

\author{
Matthew L. Zwicker ${ }^{*}$ and Robert J. Sinclair ${ }^{\dagger}$ \\ Airborne Systems North America, Santa Ana, CA, 92704
}

\begin{abstract}
The development and testing of the Orion crew capsule parachute system has provided a unique opportunity to study dense parachute packing techniques and limits, in order to establish a new baseline for future programs. The density of parachute packs has a significant influence on vibration loads, retention system stresses, and parachute mortar performance. Material compositions and pack densities of existing designs for space capsule recovery were compared, using the pack density of the Apollo main parachutes as the current baseline. The composition of parachutes has changed since Apollo, incorporating new materials such as Kevlar ${ }^{\circledR}$, Vectran ${ }^{\circledR}$, Teflon ${ }^{\circledR}$ and Spectra ${ }^{\circledR}$. These materials have different specific densities than Nylon, so the densities of hybrid parachute packs cannot be directly compared to Nylon parachutes for determination of feasibility or volume allocation. Six parachute packs were evaluated in terms of weighted average solid density in order to achieve a non-dimensional comparison of packing density. Means of mitigating damage due to packing pressure and mortar firing were examined in light of the Capsule Parachute Assembly System (CPAS) and Apollo experience. Parachute design improvements including incorporation of modern materials and manufacturing processes serves to make CPAS the new knowledge base on which future spacecraft parachute systems will be built.
\end{abstract}

\section{Nomenclature}

$C P A S=$ Capsule Parachute Assembly System

$F B C P=$ Forward Bay Cover Parachute

$M I C D=$ Mechanical Interface Control Drawing

\section{Introduction}

$\mathrm{D}$ ENSELY packed parachutes are used in space and aircraft recovery systems, often requiring use of high pressures during packing to meet volume and stiffness requirements. The following is an assessment of the impact of pack density on system performance, compliance with requirements, and project resource allocation. Historically, parachute pack density has been evaluated and compared between projects using the traditional mass per volume measurement, which fails to take into account the material composition of the parachute. Current projects utilize a variety of textiles depending on the specific performance requirements of the parachute system. This requires a method of comparing pack densities which accounts for variation in material composition..

CPAS is the parachute recovery system for the NASA Orion crew capsule. The CPAS development project provides unique opportunities to enhance our knowledge of parachute design and installation into the vehicle. Spacecraft development involves compromise between subsystem requirements, and CPAS has been very successful in meeting performance and reliability requirements within mass, material, and volume limits. The CPAS design evolution has resulted in a range of pack densities for the four parachute designs in the system, each presenting its own challenges.

Main pack volume allocation and retention system configuration are critical elements of the recovery system design. Densely packed parachute bags appear rigid, but act similar to elastic materials under high acceleration and impact loads. Loads imparted on the spacecraft structure by the acceleration of the main parachute packs are affected by the rigidity of the pack, how closely it mates to the surrounding structure, and the preload produced by the retention system. Higher pack densities result in more rigid packs, which remain coupled more closely to the structure and reduce stress induced in the attachment points by acceleration and deformation of the packed mass.

\footnotetext{
* Systems Engineer, Space and Recovery Division, 3000 Segerstrom Ave, Santa Ana, CA, AIAA Member.

${ }^{\dagger}$ Chief Engineer, Space and Recovery Division, 3000 Segerstrom Ave, Santa Ana, CA, Associate Fellow.
}

1

American Institute of Aeronautics and Astronautics 
Successfully increasing main pack density on CPAS has improved clearance with the volume limits, and allowed weight growth of main parachutes without additional volume as requirements have changed. Increased clearance reduces the risk of contact between the hot surrounding surfaces and the pack, and reduces the likelihood of damage to parachutes during forward bay cover liftoff. During periods of vibration or high acceleration, the retention system and bag shape deflect, reducing clearance with nearby components. For this reason, a buffer region was defined within the volume allocated for the CPAS main parachutes, requiring that the installed main packs occupy less volume than the spacecraft Mechanical Interface Control Drawing (MICD) allows.

Further mass growth of CPAS parachutes could occur if required by changes in vehicle weight or landing requirements. Increasing the size of main parachutes, and as a result the pack masses, may necessitate an increase in packed density or more efficient volume utilization in order to remain within volume limits. This proved to be the case for the Apollo parachute system, as shown in Table 1.

Table 1. Volumetric Requirements of Apollo Main Parachute Pack. ${ }^{1}$

\begin{tabular}{|c|c|c|c|c|}
\hline $\begin{array}{c}\text { Earth Landing } \\
\text { System test programs }\end{array}$ & $\begin{array}{c}\text { Volume of main } \\
\text { parachute pack } \\
\text { assembly, in }\end{array}$ & $\begin{array}{c}\text { Net usable } \\
\text { volume, } \\
\text { in }^{3}\end{array}$ & $\begin{array}{c}\text { Volumetric } \\
\text { efficiency of } \\
\text { parachute pack, } \\
\text { percent }\end{array}$ & $\begin{array}{c}\text { Main-parachute } \\
\text { pack density, } \\
\text { lbm/ft }\end{array}$ \\
\hline Block I & 5089 & 6808 & 74.8 & 41.3 \\
\hline Block II & 5500 & 6925 & 79.4 & 41.6 \\
\hline $\begin{array}{c}\text { Increased Capability } \\
\text { Block II }\end{array}$ & 5500 & 6925 & 79.4 & 42.7 \\
\hline
\end{tabular}

\section{Previous Research}

T.W. Knacke published a detailed analysis of dense parachute packing techniques in 1961. This report demonstrated that increased packing pressure results in increased pack density, with diminishing returns ${ }^{2}$. Figure 1 shows a density vs. pressure curve for a solid flat Nylon parachute used in the study. Knacke found that parachute type (ribbon or flat, for example), press rate, and packing methods had little impact on final density, and resolved the relationship down to only density vs. pressure.

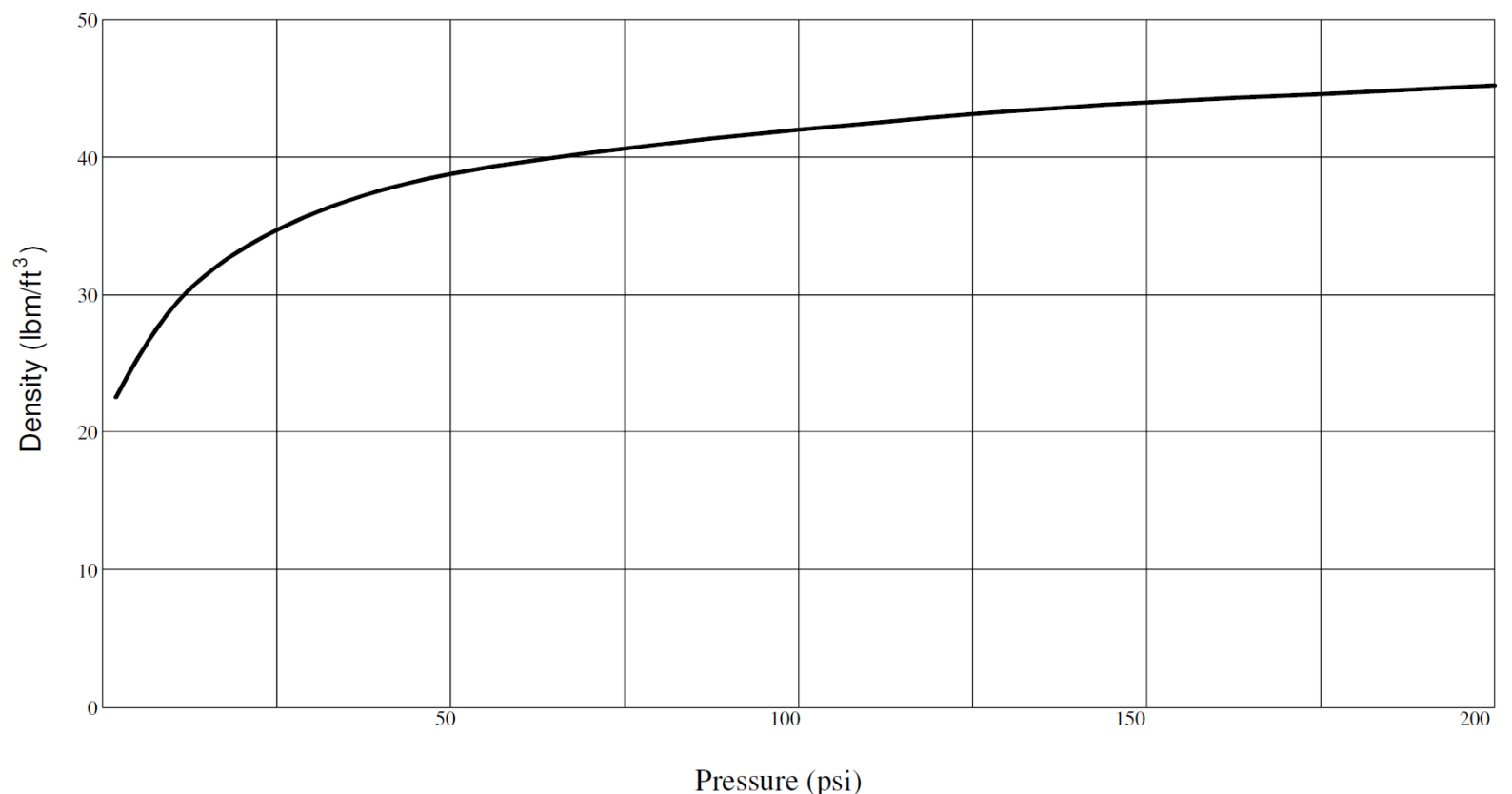

Figure 1. Data from T.W. Knacke Pack Density Study - Solid flat Nylon Parachute. ${ }^{2}$

The top of the curve shows a density greater than $45 \mathrm{lbm} / \mathrm{ft}^{3}$ at $200 \mathrm{psi}$, which would be an improvement on the $42.7 \mathrm{lbm} / \mathrm{ft}^{3}$ at $300 \mathrm{psi}$ experienced on the Apollo main parachutes. The difference can be explained by packing fixture shape. Cylindrical fixtures typically produce better packing efficiency than other shapes, and Knacke used 
cylindrical fixtures to obtain the above data. Comparing the density of a cylindrical pack with irregular pack shapes should be done conservatively and effort should be made by designers to find packs of similar shape for direct comparison.

All of the parachutes involved in the original Knacke study were Nylon, as were virtually all parachutes in use at the time. Since then, engineers have adopted new fibers such as Kevlar®, Vectran ${ }^{\circledR}$, and Spectra ${ }^{\circledR}$ in parachute design. Understanding pack density in light of the emergence of these hybrid parachutes requires examination not just of pressure and density, but also mass fractions of the materials comprising each parachute. Knacke's original research showed that whether the materials being pressed are lines, ribbons, webbing, or fabric is less important than the pressure applied. At zero pressure, broadcloth may appear to have lower density than webbing, but at high density the majority of the air has been removed from the pack and the fibers are organized primarily by pressure instead of weaving arrangement. With parachutes constructed of a mix of materials, the mass fractions of different materials in addition to applied pressure are the important variables when comparing packs of similar shape. Accounting for mass fractions of the included materials does not conflict with Knacke's work, but creates another variable to evaluate modern designs.

\section{Comparison of CPAS and Apollo Experience}

Use of main parachute packs at densities greater than $40 \mathrm{lbm} / \mathrm{ft}^{3}$ created challenges for both Apollo and CPAS. Comparison of Apollo reports with CPAS experience shows that Apollo encountered dramatically greater difficulty in achieving these pack densities ${ }^{1-5}$. Some of the reduction in difficulty can be attributed to experience gained since Apollo. Many of the Apollo packing innovations are now commonplace in the parachute industry, including lowfriction (Teflon ${ }^{\circledR}$ or Spectra ${ }^{\circledR}$ ) fabric bag liners, rigid packing fixtures, press and soak sequences including intermediate steps, and the use of vacuum. Each of these technologies is common between CPAS and Apollo, but CPAS was able to achieve greater than $40 \mathrm{lbm} / \mathrm{ft}^{3}$ density with much less difficulty.

Producing the final pack density of $42.7 \mathrm{lbm} / \mathrm{ft}^{3}$ in the Apollo main parachutes required packing pressures of 300 psi, complex multi-stage packing techniques, and long soak stages under high pressure. CPAS has achieved an average pack density of $47.0 \mathrm{lbm} / \mathrm{ft}^{3}$ using pressures of only $154 \mathrm{psi}$ and less total soak time. One important advancement made since Apollo is the use of autoclave cycles under vacuum after the packing fixture is sealed, which serves to solidify the packs, remove moisture, and reduce changes in bag shape after installation in the parachute compartment. Apollo packed under vacuum and then delivered the sealed pack to the flight vehicle without an autoclave cycle ${ }^{4}$. CPAS applies vacuum only after the packing process is completed, and utilizes an autoclave cycle of the packed and sealed fixture ${ }^{6}$.

Table 2 gives a summary of the pack press sequences for three main parachutes. The Apollo and CPAS main parachutes are included in addition to a third space capsule parachute development project to expand the comparison. The three main parachutes compared are of similar type and container shape, varying by size, mass, and material composition. The relative shapes of the three packs can also be exlamined in Figure 2. 
Table 2a. Apollo Main Parachute Pack Press Sequence ${ }^{4}$

\begin{tabular}{|c|c|c|c|c|}
\hline Pressure & $\begin{array}{c}\text { Foot } \\
\text { Area }\end{array}$ & $\begin{array}{c}\text { Press } \\
\text { Force }\end{array}$ & $\begin{array}{c}\text { Soak } \\
\text { Time }\end{array}$ & Notes \\
\hline psi & in & lbf & Hours & Repeated 3 times \\
\hline 300 & 28 & 8,400 & 0.25 & Repeated 7 times for canopy folds \\
\hline 300 & 121 & 36,300 & 0.5 & Long soak for the canopy fabric \\
\hline 300 & 121 & 36,300 & 8.0 & Cutters packed after long soak \\
\hline 150 & 121 & 18,150 & 0.5 & First layer of suspension lines \\
\hline 150 & 121 & 18,150 & 0.5 & Second layer of suspension lines \\
\hline 200 & 121 & 24,200 & 0.5 & Third layer of suspension lines \\
\hline 250 & 121 & 30,250 & 0.5 & Press riser links (2 times) \\
\hline 250 & 121 & 30,250 & $1.0+0.5$ & Final soak with stowed riser \\
\hline 226 & 159 & 36,000 & 12.0 & \\
\hline
\end{tabular}

Table 2b. CPAS Main Parachute Pack Press Sequence ${ }^{6}$

\begin{tabular}{|c|c|c|c|c|}
\hline Pressure & $\begin{array}{c}\text { Foot } \\
\text { Area }\end{array}$ & $\begin{array}{c}\text { Press } \\
\text { Force }\end{array}$ & $\begin{array}{c}\text { Soak } \\
\text { Time }\end{array}$ & Notes \\
\hline psi & in & lbf & Hours & Canopy fabric \\
\hline 154 & 246 & 38,000 & 0.5 & Canopy fabric \\
\hline 101 & 396 & 40,000 & 0.5 & Canopy, except skirt \\
\hline 114 & 396 & 45,000 & 17.0 & Canopy with skirt \\
\hline 76 & 396 & 30,000 & 0.5 & First group of suspension lines \\
\hline 76 & 396 & 30,000 & 0.5 & Lines up to the riser \\
\hline 55 & 549 & 30,000 & 0.5 & Canopy, lines, riser (final) \\
\hline 46 & 549 & 25,000 & 0.5 & \\
\hline
\end{tabular}

Table 2c. Airborne Development Project Main Parachute Press Sequence

\begin{tabular}{|c|c|c|c|c|}
\hline Pressure & $\begin{array}{c}\text { Foot } \\
\text { Area }\end{array}$ & $\begin{array}{c}\text { Press } \\
\text { Force }\end{array}$ & $\begin{array}{c}\text { Soak } \\
\text { Time }\end{array}$ & Notes \\
\hline psi & in $^{2}$ & lbf & Hours & Canopy fabric \\
\hline 42 & 96 & 4,000 & 0.5 & Canopy fabric, repeated 2 times \\
\hline 36 & 220 & 8,000 & 0.5 & Canopy, except skirt \\
\hline 26 & 390 & 10,000 & 12 & Canopy with skirt \\
\hline 26 & 390 & 10,000 & 0.5 & Canopy, lines, riser \\
\hline 38 & 390 & 15,000 & 0.5 & Canopy, lines, riser (final) \\
\hline 57 & 635 & 36,000 & 0.5 & \\
\hline
\end{tabular}

The Apollo main parachutes were over $91 \%$ Nylon, with some Nomex ${ }^{\circledR}$, Teflon ${ }^{\circledR}$, and Polyester used in the deployment bags. The CPAS main parachutes are nearly 55\% Kevlar® by weight, with Nylon used for broadcloth and minor components, along with some Vectran ${ }^{\circledR}$ and Spectra ${ }^{\circledR}$ in small quantities. Kevlar ${ }^{\circledR}$ has a specific density of $90.5 \mathrm{lbm} / \mathrm{ft}^{3}$, compared to $71.2 \mathrm{lbm} / \mathrm{ft}^{3}$ for Nylon. Materials with higher specific densities (Kevlar ${ }^{\circledR}$, Vectran ${ }^{\circledR}$ ) can be packed to high densities with less pressure than materials of low specific densities (Nylon, Spectra ${ }^{\circledR}$, 
Nomex $($ ). Tables 3, 4 and 6 through 9 examine the mass breakdown for several parachutes by material, and use a weighted average to develop an equivalent solid density for each parachute. The weighted average solid density is the limit of what could be achieved if the packing ram force was increased without limit until all of the air was pressed out of the parachute, rendering it a solid block of material. In practice this is not achievable, but it serves as a reference density for comparison. This technique allows a non-dimensional assessment of pack densities, which facilitates direct comparison of packing schemes regardless of material composition.

The Apollo main parachute at an average density of $42.7 \mathrm{lbm} / \mathrm{ft}^{3}$ is packed to $59.8 \%$ of solid density, while the CPAS main parachute at an average density of $47.0 \mathrm{lbm} / \mathrm{ft}^{3}$ is packed to $57.5 \%$ of solid density. Though the total density is over $10 \%$ higher, the CPAS main parachute requires far less pressure and effort to approach the $59.8 \%$ of solid benchmark set by Apollo. If the CPAS main parachute was packed to Apollo's 59.8\% of max density, it would achieve a total density of $48.9 \mathrm{lbm} / \mathrm{ft}^{3}$, which indicates room to increase the CPAS main parachute mass slightly if project requirements change.

The difference between CPAS and Apollo in difficulty of dense packing is not explained entirely by the difference in specific density of materials. The higher pressure used in the Apollo packing process was partially driven by the tall, narrow wedge shape of the Apollo pack. The Apollo pack was curved around the spacecraft as well, so the Apollo main packing fixtures used a rotating configuration, inserting the parachute from the side. This allowed the tall and slender curved pack design while maintaining a uniform cross section during packing. The CPAS pack shape is partially conical, with the pack narrowing toward the top as shown in Figure 2. The CPAS main is packed from the bottom of the bag, with the bag inverted into a tapered packing fixture. This changes the cross section of the pack throughout the press sequence, resulting in the variety of press foot areas shown in Table 2 . The relative ease of creating dense packs using cylindrical fixtures is well known ${ }^{2}$, so this paper divides the packs evaluated into cylindrical and wedge-shaped packs to create a more meaningful comparison.

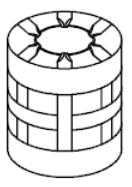

CPAS FBCP

Diameter: 7.65 in

Height: 7.28 in

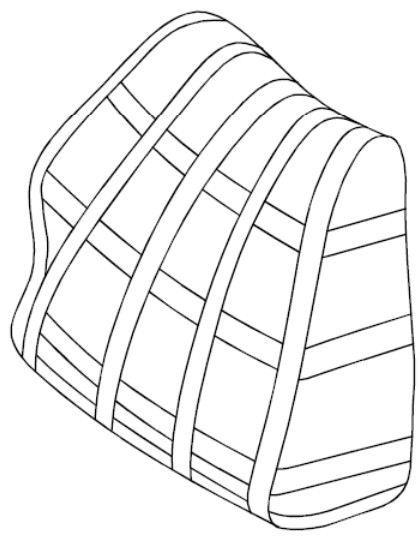

Apollo Main

Volume: $3.17 \mathrm{ft}^{3}$

Density: $42.7 \mathrm{lb} / \mathrm{ft}^{3}$

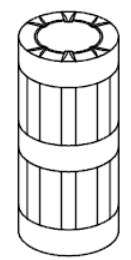

CPAS Pilot

Diameter: 6.70 in

Height: 13.0 in

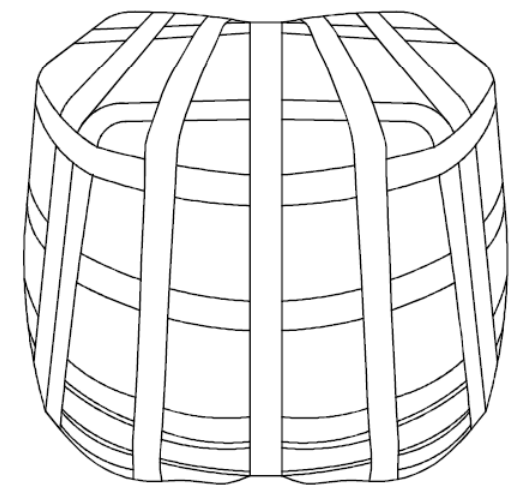

CPAS Main

Volume: $5.89 \mathrm{ft}^{3}$

Density: $47.0 \mathrm{lb} / \mathrm{ft}^{3}$

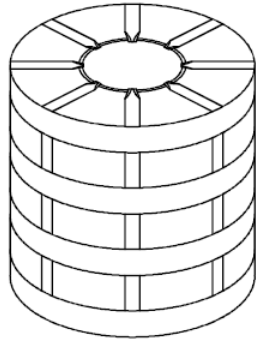

CPAS Drogue

Diameter: 16.4 in

Height: 14.1 in

Figure 2. Size and Shape Comparison of Packs.

(Drawings are to Scale)

American Institute of Aeronautics and Astronautics 
Each of the six parachutes depicted in Figure 2 was evaluated by summing the total specified mass of all components of each material to achieve a breakdown by mass fraction, which is then used to calculate the weighted average solid density. The mass divided volume gives total density, which can be compared to the weighted average solid density to determine the $\%$ of solid density achieved by the packing process. Since this effort is interested only in the effect on the parachute itself, the deployment bags and metallic items are not considered in the mass breakdown or total density calculation for the CPAS parachutes.

To determine accurate volumes for use in total density calculation, CAD models were created for each parachute, subtracting a small thickness from the external surfaces to reduce volume to account for removal of the deployment bag. Consistent thickness reduction was used for all the parachutes, and based on measurements and examination of packed deployment bags. The purpose of this analysis is comparison of density between packs, so consistently applying the volume reduction to account for bag removal eliminates errors in comparison. Due to the difficulty in accurately determining the dimensions of the Apollo fixtures and thicknesses of the deployment bag materials used, the Apollo deployment bag is included in the density calculation and mass breakdown. The absence of Kevlar ${ }^{\circledR}$ in the Apollo deployment bag reduces the effect of including it in the analysis, so a valid comparison can still be made with the other examples.

\section{A. Apollo Main Parachute}

The Apollo main parachutes were a $85.5 \mathrm{ft}$ Do Ringsail design ${ }^{8}$ packed into a wedge-shaped fixture so the three resulting main packs would fit the conical shape of the parachute compartment in the forward bay. Apollo encountered textile damage caused by high packing pressures, primarily due to contact between reefing rings and textiles under press. The damage was reduced through careful packing, and highly refined packing fixture design, and design of a custom double reefing ring with generous rounded corners to protect surrounding textiles. In order to refine their state of the art high density packing technique, Apollo performed 70 practice packs on main parachutes over a period of one year. Shop space and personnel were set aside for the purpose of developing techniques to fit the main parachutes in the allocated volume. Project budgets should account for extra time in developing custom packing processes to accomplish difficult shapes and high densities, and for studying the effects on materials and components. Damage from packing was steadily reduced during the Apollo pack development, but the team eventually accepted that small cuts in fabric due to reefing rings and bent reefing cutters would sometimes occur and were normal for the system.

Table 3. Mass Breakdown of Apollo Main Parachute. ${ }^{8-9}$

\begin{tabular}{|c|c|c|c|}
\hline \multicolumn{3}{|c|}{ (Includes Deployment Bag) } & \\
\hline & Fraction & Density & \\
\hline Material & $\%$ & $\mathbf{l b m} / \mathbf{f t}^{3}$ & \\
\hline Nylon & $91.4 \%$ & 71.17 & \\
\hline Nomex ${ }^{\circledR}$ & $3.4 \%$ & 41.83 & \\
\hline Teflon ${ }^{\circledR}$ & $0.8 \%$ & 137.34 & \\
\hline Dacron ${ }^{\circ}$ & $4.4 \%$ & 87.40 & \\
\hline Total: & $100.0 \%$ & & \\
\hline \multicolumn{2}{|c|}{ Weighted Average Solid Density = } & 71.4 & $\mathrm{lbm} / \mathrm{ft}^{3}$ \\
\hline & Solid Volume = & 1.90 & $\mathrm{ft}^{3}$ \\
\hline \multicolumn{2}{|c|}{ Final Packed Volume $=$} & 3.18 & $\mathrm{ft}^{3}$ \\
\hline \multicolumn{2}{|c|}{ Final Packed Density $=$} & 42.7 & $\mathrm{lbm} / \mathrm{ft}^{3}$ \\
\hline \multicolumn{2}{|c|}{$\%$ of Solid Density Achieved $=$} & $59.8 \%$ & \\
\hline
\end{tabular}

Apollo eventually incorporated a custom double reefing ring strong enough to withstand the high pressure in the packs and with sufficiently radiused edges to protect neighboring textiles. The cost of the custom component was justified in order to reduce ring cuts during packing to an acceptable level for flight. In addition, cutter damage during packing necessitated the use of thick padded cutter pockets, as shown in Figure 3. 


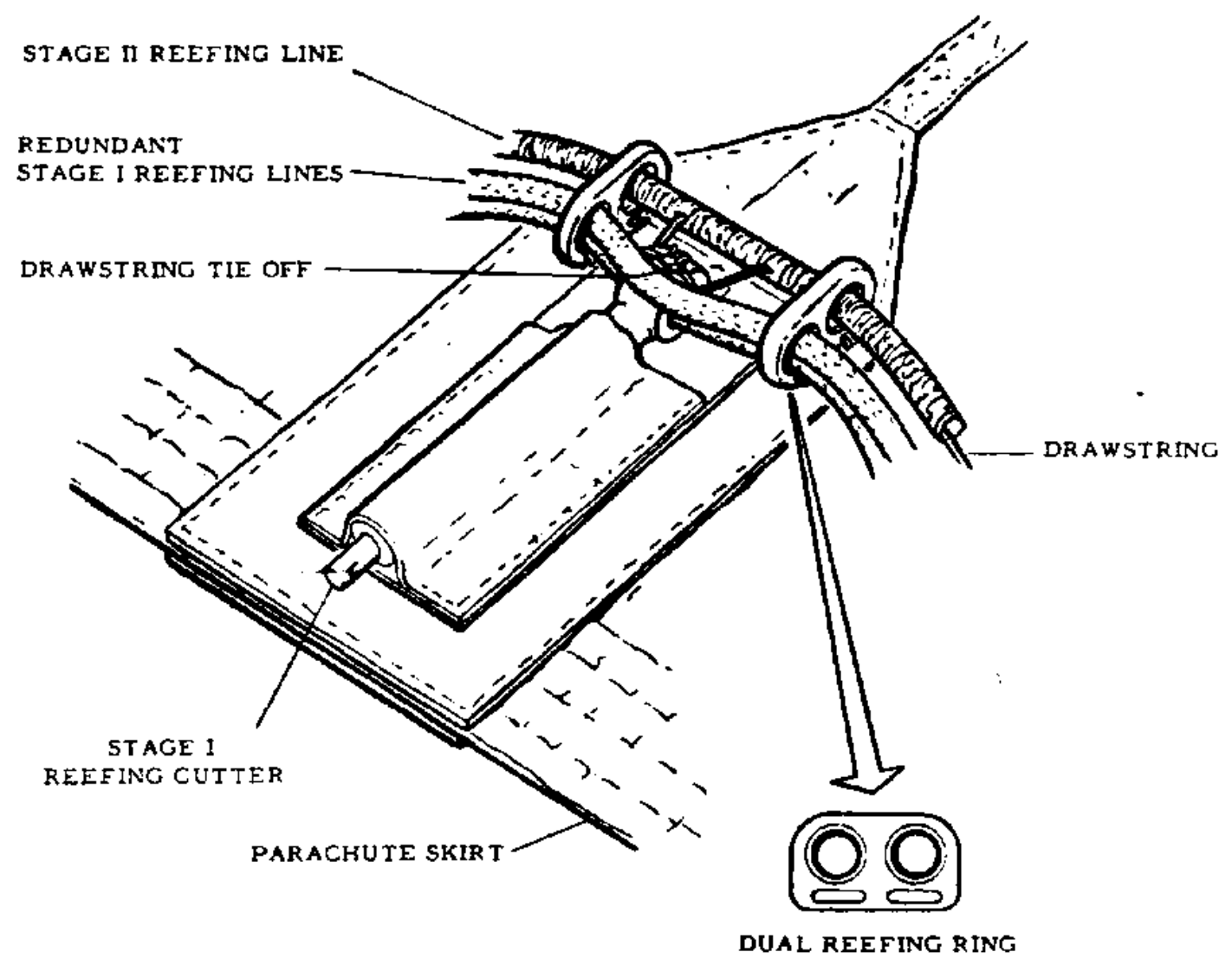

Figure 3. Apollo Reefing Ring and Cutter Pocket Design. ${ }^{3}$

\section{B. CPAS Main Parachute}

The CPAS main parachutes are a 116ft Do Ringsail design, utilizing a Kevlar® structural grid, lines, and riser, and Nylon broadcloth for the sails. It has the highest percentage of Nylon by weight of any of the CPAS parachutes, but it is still nearly 55\% Kevlar®. The CPAS Main parachute uses a trailing distance of over 200ft, which requires the use of a long Kevlar ${ }^{\circledR}$ riser $^{10}$. The riser length increases the mass fraction of Kevlar ${ }^{\circledR}$ in the main pack, which contributes to the high pack density achieved. The mass breakdown for a CPAS main parachute is given in Table 4.

Table 4. Mass Breakdown of CPAS Main Parachute. ${ }^{10}$ Excludes Deployment Bag and Metallic Items

\begin{tabular}{|c|c|c|c|}
\hline & Fraction & Density & \\
\hline Material & $\%$ & $\mathbf{l b m} / \mathbf{f t}^{3}$ & \\
\hline Kevlar® & $54.5 \%$ & 90.52 & \\
\hline Nylon & $44.9 \%$ & 71.17 & \\
\hline Vectran $\AA$ & $0.3 \%$ & 87.40 & \\
\hline Spectra ${ }^{\circledR}$ & $0.3 \%$ & 60.56 & \\
\hline Total: & $100.0 \%$ & & \\
\hline \multicolumn{2}{|c|}{ Weighted Average Solid Density = } & 81.7 & $\mathrm{lbm} / \mathrm{ft}^{3}$ \\
\hline & Solid Volume $=$ & 3.39 & $\mathrm{ft}^{3}$ \\
\hline \multicolumn{2}{|c|}{ Final Packed Volume $=$} & 5.89 & $\mathrm{ft}^{3}$ \\
\hline \multicolumn{2}{|c|}{ Final Packed Density = } & 47.0 & $\mathrm{lbm} / \mathrm{ft}^{3}$ \\
\hline \multicolumn{2}{|c|}{$\%$ of Solid Density Achieved $=$} & $57.5 \%$ & \\
\hline
\end{tabular}

As heir to the Apollo heritage, many of the CPAS performance requirements are similar to or based on Apollo experience. Early pack density estimates for CPAS were based on a simple calculation of mass divided by the 
volume allocated for the parachute bags, and were expected to be approximately $38.1 \mathrm{lbm} / \mathrm{ft}^{3}$. This estimate was conservative, and lower than the upper limit achieved on the Apollo program of $42.7 \mathrm{lbm} / \mathrm{ft}^{3}$. In practice, the CPAS main pack design could not utilize all of the volume allocated, which resulted in a higher average density than intended. The volume of the packed bag was reduced from the allotted volume by imperfect "filling out" of the packing fixture during pressing. This is a normal occurrence in fixtures with sharp corners, and the CPAS bags end up with corner radii as large as 3" in some areas. Concerns about pack deflection during high vibration loads drove a requirement to increase clearance with the MICD boundaries, which necessitated a reduction in height of the packed bag as the design evolved. These changes caused the CPAS main pack density to climb to an average of 47.0 $\mathrm{lbm} / \mathrm{ft}^{3}$, which is over $20 \%$ higher than initial estimate of $38.1 \mathrm{lbm} / \mathrm{ft}^{3}$ predicted.

CPAS encountered the same difficulties in producing dense packs as Apollo, though to a greatly reduced degree. Though CPAS main packs require rigid metallic fixtures and hydraulic packing presses (at over 40,000 lbf), the degree of difficulty, the number of packing technique iterations, and the resulting damage to textiles has been much less severe than Apollo experience predicted. Design changes to the parachutes, specifically the reefing system, have contributed to the reduction in packing damage frequency.

The CPAS main parachute design incorporates recent research including an all-textile reefing loop system in place of traditional steel rings. Textile reefing loops eliminate stress concentrations in the textiles surrounding steel reefing rings, and also preclude damage to the rings themselves. The textile reefing loop concept has proven to be highly robust and capable of being retrofitted to existing designs to replace steel rings. More tensile testing and design qualification are needed to ensure textile loops are adequate for all performance criteria, but the elimination of risk and complexity by simplification of dense packing justified the effort on CPAS. The primary cause of textile damage on Apollo's flight configuration was reefing ring contact, so the elimination of reefing rings from main parachutes may provide an opportunity to increase density and save additional volume on future development projects.

To study the effect of high pack densities on the strengths of included materials, material samples were placed in a CPAS main pack pressed to flight density. This main parachute was left packed for months while being used for ground testing. It was later unpacked and the samples were removed, tensile tested, and compared to control material to determine if any degradation had occurred due to packing. Table 5 shows the results of these tests.

Table 5. CPAS Main Parachute Material Test Results.

\begin{tabular}{|l|c|c|c|c|}
\hline Material & $\begin{array}{c}\text { Minimum } \\
\text { Specified Strength }\end{array}$ & $\begin{array}{c}\text { Average Control } \\
\text { Strength }\end{array}$ & $\begin{array}{c}\text { Average Strength } \\
\text { After Packing }\end{array}$ & $\begin{array}{c}\text { \% Change in } \\
\text { Strength }\end{array}$ \\
\hline $2.0 \mathrm{oz}$ Nylon Ripstop & $90.0 \mathrm{lbf} / \mathrm{in}$ & $94.9 \mathrm{lbf} / \mathrm{in}$ & $93.9 \mathrm{lbf} / \mathrm{in}$ & $-1.05 \%$ \\
\hline $1.17 \mathrm{oz}$ Nylon Ripstop & $45 \mathrm{lbf} / \mathrm{in}$ & $55.1 \mathrm{lbf} / \mathrm{in}$ & $55.7 \mathrm{lbf} / \mathrm{in}$ & $+1.09 \%$ \\
\hline $1.10 \mathrm{oz}$ Nylon Ripstop & $42 \mathrm{lbf} / \mathrm{in}$ & $48.2 \mathrm{lbf} / \mathrm{in}$ & $48.6 \mathrm{lbf} / \mathrm{in}$ & $+0.83 \%$ \\
\hline Kevlar® Cord & $1,800 \mathrm{lbf}$ & $2,315 \mathrm{lbf}$ & $2,240 \mathrm{lbf}$ & $-3.24 \%$ \\
\hline Kevlar® Cord & $6,500 \mathrm{lbf}$ & $6,780 \mathrm{lbf}$ & $6,800 \mathrm{lbf}$ & $+0.29 \%$ \\
\hline Kevlar® Tape & $2,400 \mathrm{lbf}$ & $3,047 \mathrm{lbf}$ & $2,938 \mathrm{lbf}$ & $-3.58 \%$ \\
\hline
\end{tabular}

The materials did not experience significant degradation due to packing. The small percentage changes shown are explained by the small number of samples included in the pack, and natural variation in parachute materials. This method of material damage assessment is easy to implement, and can provide a low-cost means of evaluating whether the density of a pack could be increased without degradation of materials. CPAS reduced the cost of the packed material degradation study by incorporating the samples into packs slated for use in other ground tests. Main parachute packing experience on CPAS has not revealed any other forms of high-pressure packing damage during inspection, such as stress concentrations at creases causing failures of Nylon fabric. Consistently positive results from the combination of sample testing and detailed inspections of canopies indicates that the CPAS main parachutes are not suffering degradation from the current packing configuration.

\section{Airborne Development Project Main Parachute}

Table 6 gives packing density information for another Airborne development project, featuring a Ringsail parachute to be used in a cluster for space capsule recovery. This main parachute is included to provide an additional example to contrast between the CPAS and Apollo main parachutes, which are both mature designs. The CPAS main parachute is a hybrid design incorporating Kevlar ${ }^{\circledR}$ structure with Nylon canopy material, so it is useful to have another hybrid parachute of similar type for comparison. Space capsule development projects typically grow in mass and complexity as their designs progress ${ }^{1}$, and comparison of this example to the Apollo and CPAS main parachute packing data shows a design well-positioned to absorb main parachute mass growth without need for further volume allocation. 
Table 6. Mass Breakdown of Development Main Parachute.

Excludes Deployment Bag and Metallic Items

\begin{tabular}{|c|c|c|c|}
\hline & & & \\
\hline & Fraction & Density & \\
\hline Material & $\%$ & $\mathrm{lbm} / \mathbf{f t}^{3}$ & \\
\hline Kevlar® & $38.0 \%$ & 90.52 & \\
\hline Nylon & $61.3 \%$ & 71.17 & \\
\hline Vectran $®$ & $0.2 \%$ & 87.40 & \\
\hline Spectra® & $0.1 \%$ & 60.56 & \\
\hline Teflon $®$ & $0.4 \%$ & 137.34 & \\
\hline Total: & $100.0 \%$ & & \\
\hline \multicolumn{2}{|c|}{ Weighted Average Solid Density $=$} & 78.8 & $\mathrm{lbm} / \mathrm{ft}^{3}$ \\
\hline & Solid Volume $=$ & 1.86 & $\mathrm{ft}^{3}$ \\
\hline \multicolumn{2}{|c|}{ Final Packed Volume $=$} & 3.77 & $\mathrm{ft}^{3}$ \\
\hline \multicolumn{2}{|c|}{ Final Packed Density $=$} & 38.9 & $\mathrm{lbm} / \mathrm{ft}^{3}$ \\
\hline \multicolumn{2}{|c|}{$\%$ of Solid Density Achieved $=$} & $49.3 \%$ & \\
\hline
\end{tabular}

Mortar Deployed Parachutes

CPAS utilizes three mortar deployed parachute designs, each packed into a cylindrical fixture. The packing densities of cylindrical parachute packs are typically higher for a given pressure than rectangular or wedge shaped packs $^{2}$. For this reason, the comparison of packs is divided into cylindrical and wedge shaped designs. The three cylindrical packs utilized on CPAS are of different sizes, masses, and material compositions as shown in Figure 2 and Tables 7-9. They are all packed in the same facility utilizing similar equipment and techniques, so a comparison between them can be made without error contributed by those factors.

\section{CPAS Drogue Parachute}

The CPAS drogue parachute is a $23 \mathrm{ft}$ Variable Porosity Conical Ribbon parachute, utilizing a Kevlar® structural grid, lines and riser and 2.0 in wide Nylon ribbons as the canopy material. The drogue is packed to about $40 \%$ of its solid density, making it the softest of the CPAS packs as shown in Table 7.

Table 7. Mass Breakdown of CPAS Drogue Parachute. ${ }^{11}$ Excludes Deployment Bag and Metallic Items

\begin{tabular}{|c|c|c|c|}
\hline & Fraction & Density & \\
\hline Material & $\%$ & $\mathbf{l b m} / \mathbf{f t}^{3}$ & \\
\hline Kevlar® & $85.6 \%$ & 90.52 & \\
\hline Nylon & $13.6 \%$ & 71.17 & \\
\hline Vectran $®$ & $0.3 \%$ & 87.40 & \\
\hline Spectra® & $0.4 \%$ & 60.56 & \\
\hline Total: & $100.0 \%$ & & \\
\hline \multicolumn{2}{|c|}{ Weighted Average Solid Density = } & 87.8 & $\mathrm{lbm} / \mathrm{ft}^{3}$ \\
\hline & Solid Volume = & 0.65 & $\mathrm{ft}^{3}$ \\
\hline \multicolumn{2}{|c|}{ Final Packed Volume $=$} & 1.63 & $\mathrm{ft}^{3}$ \\
\hline \multicolumn{2}{|c|}{ Final Packed Density = } & 34.9 & $\mathrm{lbm} / \mathrm{ft}^{3}$ \\
\hline \multicolumn{2}{|c|}{$\%$ of Solid Density Achieved = } & $39.7 \%$ & \\
\hline
\end{tabular}

Of the three types of mortar-deployed parachutes used on CPAS, the drogue parachute is the only one that requires reefing. The relative softness of the packed drogue allows compression of the pack during mortar firing as illustrated in Figure 4. Scaling from high speed video shows a minimum height for this mortar test of 10.67 in, which is a $24 \%$ reduction in volume from the nominal packed height of $14.1 \mathrm{in}$. 

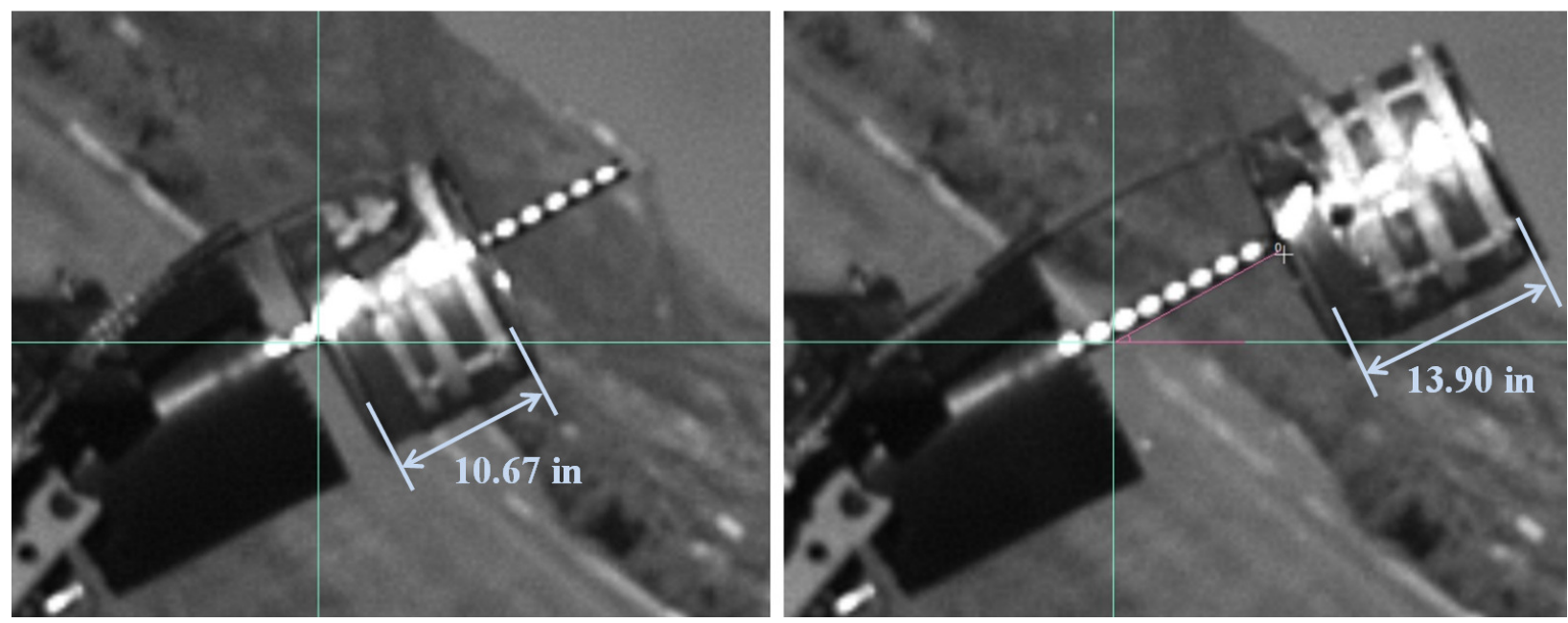

Figure 4. CPAS Drogue Pack Compression by Pneumatic Mortar Shot.

Nominal Height of Drogue Pack $=14.1$ in

During drogue packing, the final soak step is sufficiently long that the pack does not expand significantly during transfer between the packing fixture and the mortar. When the pack is inserted in the mortar, the lid is pressed in place and the pack is held at flight density by the constraints of the internal mortar volume. If the pack is too soft and compresses significantly during mortar firing, it reaches a size much smaller than the minimum volume achieved during packing. The compression results in the maximum density and internal pressure occurring in an instantaneous fashion during mortar firing, instead of a controlled fashion during packing. This is undesirable from the standpoint of textile, reefing ring, and cutter damage, and required additional testing on CPAS to quantify the risks to drogue performance. Compression to $76 \%$ of initial height corresponds to a pack density of $46.0 \mathrm{lbm} / \mathrm{ft}^{3}$, or $52 \%$ of solid density. This would be an easy pack density to achieve with a hydraulic press on a cylindrical fixture, and reducing the mortar volume to $76 \%$ of current volume as a nominal pack density would result in reduced risk of damage to reefing components.

Textile reefing loops can eliminate the risk of reefing ring damage to textiles during mortar firing, but a means of protecting reefing cutters from damage was required on CPAS drogues in response to cutter damage during pneumatic mortar testing. The commercially available reefing cutters were rigged with an external protective sleeve of stainless steel, bonded closely to the cutter body using a flexible adhesive. The custom sleeves have large radii and smooth surfaces to protect the surrounding textiles, and serve to provide bending stiffness to support the relatively thin cutter bodies during mortar firing. This approach has been used to good results in both the very soft, mortar-deployed CPAS drogue and the very dense, pilot-deployed CPAS main parachutes. Experience with custom cutter sleeves on CPAS suggests that reefing cutter geometry is not a barrier to high or low pack density, provided the sleeve design is tested against the specific service requirements.

\section{E. CPAS Pilot Parachute}

The CPAS pilot parachutes are $9.85 \mathrm{ft}$ Do conical ribbon parachutes with a Kevlar ${ }^{\circledR}$ structural grid, lines and riser and 2.0 in Nylon ribbons as the canopy material. They are the most densely packed of the CPAS parachutes, both in terms of total density and \% of solid density, at 58.0\% as shown in Table 8 . This approaches the 59.8\% density of the Apollo main parachutes, though no damage due to packing has been noted in the CPAS pilots. The pilot parachutes contain no cutters or reefing rings, which were the primary source of fabric damage on both the Apollo and CPAS main parachutes. This suggests that if mass growth of the pilot parachutes was needed, it may not be necessary to allocate additional volume in the mortar. Rigging experience has shown this to be the case, as the pilot parachutes are typically easy to pack, often being hand-tamped into the fixture rather than pressed by a hydraulic ram. This experience is consistent with other mortar-deployed parachute packs which utilize relatively long and slender cylindrical packs. 
Table 8. Mass Breakdown of CPAS Pilot Parachute. ${ }^{12}$

Excludes Deployment Bag (no metallic items used)

\begin{tabular}{|c|c|c|c|}
\hline & & & \\
\hline & Fraction & Density & \\
\hline Material & $\%$ & $\mathbf{l b m} / \mathbf{f t}^{3}$ & \\
\hline Kevlar® & $78.8 \%$ & 90.52 & \\
\hline Nylon & $14.1 \%$ & 71.17 & \\
\hline Vectran $®$ & $0.2 \%$ & 87.40 & \\
\hline Spectra $®$ & $1.6 \%$ & 60.56 & \\
\hline Nomex $\AA$ & $5.2 \%$ & 41.83 & \\
\hline Total: & $100.0 \%$ & & \\
\hline \multicolumn{2}{|c|}{ Weighted Average Solid Density = } & 82.6 & $\mathrm{lbm} / \mathrm{ft}^{3}$ \\
\hline & Solid Volume $=$ & 0.14 & $\mathrm{ft}^{3}$ \\
\hline \multicolumn{2}{|c|}{ Final Packed Volume $=$} & 0.25 & $\mathrm{ft}^{3}$ \\
\hline \multicolumn{2}{|c|}{ Final Packed Density $=$} & 47.9 & $\mathrm{lbm} / \mathrm{ft}^{3}$ \\
\hline \multicolumn{2}{|c|}{$\%$ of Solid Density Achieved $=$} & $58.0 \%$ & \\
\hline
\end{tabular}

\section{F. CPAS Forward Bay Cover Parachute}

The CPAS FBCPs are $7.0 \mathrm{ft}$ Variable Porosity Conical Ribbon parachutes which are constructed primarily of Kevlar®, with small amounts of other materials as shown in Table 9. The high specific density of Kevlar® suggests that a majority Kevlar ${ }^{\circledR}$ parachute could be packed to very high densities without damage. This is of particular interest with mortar deployed parachutes such as the CPAS drogue, pilot, and FBCPs. The ability to achieve highly dense and stable parachute packs can improve mortar performance and reduce the volume required for mortars and supporting structures.

Table 9. Mass Breakdown of CPAS FBCP. ${ }^{13}$

Excludes Deployment Bag (no metallic items used)

\begin{tabular}{|c|c|c|c|}
\hline \multirow{2}{*}{$\operatorname{Lict}$} & & \\
\hline & Fraction & Density & \\
\hline Material & $\%$ & $\mathbf{l b m} / \mathbf{f t}^{3}$ & \\
\hline Kevlar® & $86.1 \%$ & 90.52 & \\
\hline Vectran $®$ & $1.6 \%$ & 87.40 & \\
\hline Nomex® & $11.1 \%$ & 41.83 & \\
\hline Teflon $®$ & $1.2 \%$ & 137.34 & \\
\hline Total: & $100.0 \%$ & & \\
\hline \multicolumn{2}{|c|}{ Weighted Average Solid Density = } & 85.7 & $\mathrm{lbm} / \mathrm{ft}^{3}$ \\
\hline & Solid Volume $=$ & 0.09 & $\mathrm{ft}^{3}$ \\
\hline \multicolumn{2}{|c|}{ Final Packed Volume $=$} & 0.19 & $\mathrm{ft}^{3}$ \\
\hline \multicolumn{2}{|c|}{ Final Packed Density = } & 40.0 & $\mathrm{lbm} / \mathrm{ft}^{3}$ \\
\hline \multicolumn{2}{|c|}{$\%$ of Solid Density Achieved $=$} & $46.7 \%$ & \\
\hline
\end{tabular}

To compare the pressure vs density relationship for an all-Kevlar® parachute to Knacke's previous work with Nylon parachutes, a CPAS FBCP was pressed to a series of pressures while recording the position of the press plate in the fixture. The ram force was eventually increased to $23,000 \mathrm{lbf}$, resulting in a pressure of $500 \mathrm{psi}$ on the pack. At this pressure it achieved a density of $61.9 \mathrm{lbm} / \mathrm{ft}^{3}$ after a 5 minute soak. After removal from the fixture, the resulting pack was approximately $2 / 3$ the size of a typical CPAS FBCP packed for flight. Concerns about material damage due to the extreme packing pressures proved to be unfounded. Inspection of the parachute after pressing revealed no stitching damage or weave separation. The same parachute was later used for an extended test under high load in the High Velocity Airflow System (HIVAS) at the Naval Air Warfare Center Weapons Division in China Lake, CA. It survived the testing without exhibiting any unusual material or joint failures which would indicate packing damage. This experience indicates that higher pack densities (72\% of solid in this case) are achievable with unreefed Kevlar® ribbon parachutes. 
Table 10. Results of CPAS FBCP High Density Test Pack.

Internal Diameter of Fixture $=7.65$ in

Mass of FBCP used for test $=7.57 \mathrm{lbm}$

\begin{tabular}{|c|c|c|c|c|c|c|}
\cline { 2 - 6 } \multicolumn{1}{c|}{} & $\begin{array}{c}\text { Ram } \\
\text { Force }\end{array}$ & $\begin{array}{c}\text { Soak } \\
\text { Time }\end{array}$ & Pressure & Volume & Density & $\begin{array}{c}\% \text { of } \\
\text { Solid } \\
\text { Density }\end{array}$ \\
\hline Press \# & lbf & min & $\mathrm{psi}$ & in $^{3}$ & $\mathrm{lbm} / \mathrm{ft}^{3}$ & \\
\hline 1 & 7000 & 90 & 152 & 246 & 53.2 & $62.1 \%$ \\
\hline 2 & 14000 & 5 & 305 & 229 & 57.2 & $66.8 \%$ \\
\hline 3 & 23000 & 5 & 500 & 211 & 61.9 & $72.3 \%$ \\
\hline
\end{tabular}

The CPAS FBCP packing fixture is 7.65 in diameter, so producing 500 psi required a ram force of 23,000 lbf. This is well within the capability of available presses, but if those pressures were used on a pack the size of the CPAS $116 \mathrm{ft}$ Do main parachute, a ram force of $200,000 \mathrm{lbf}$ would be required for the $400 \mathrm{in}^{2}$ press plate.

Figure 5 shows the results of the FBCP packing study compiled into a density vs. pressure plot. Note the similarity to Figure 1. Both the Nylon and Kevlar® pressure vs. density curves are similar in shape, differing primarily by scale. This similarity is further indication that a primary factor restricting achievable pack density is the mass fractions of the composite materials, rather than construction, parachute type or size.

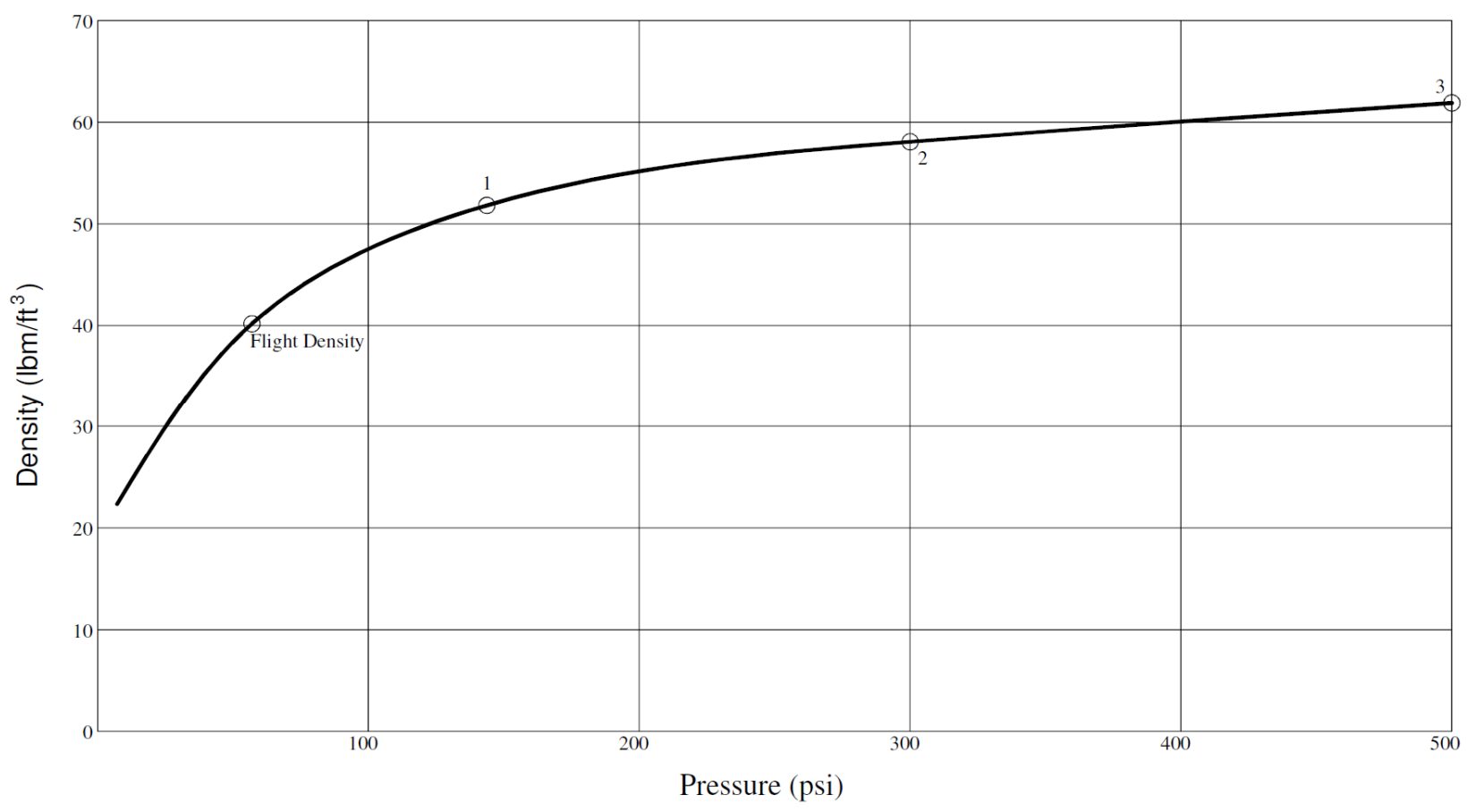

Figure 5. CPAS FBCP High Density Packing Study.

\section{Summary}

Table 11 summarizes the packing data for the main parachutes studied, and compares methods used to mitigate problems encountered. Note the similarity between the percentage of solid density achieved by both the Apollo and CPAS main parachutes. The data suggest that the CPAS main pack could still increase in density, but has reached the point of diminishing returns and a dramatic increase in packing pressure would be needed to significantly reduce volume. 
Table 11. Comparison of Main Parachutes Studied.

\begin{tabular}{|c|c|c|c|}
\hline & Apollo Main 8,9 & CPAS Main ${ }^{10}$ & Development Main \\
\hline Parachute Type & Ringsail & Ringsail & Slotted Ringsail \\
\hline Primary Material & Nylon (91\%) & Kevlar® $(55 \%)$ & Nylon $(61 \%)$ \\
\hline Weighted Average Solid Density & $71.4 \mathrm{lbm} / \mathrm{ft}^{3}$ & $81.7 \mathrm{lbm} / \mathrm{ft}^{3}$ & $78.8 \mathrm{lbm} / \mathrm{ft}^{3}$ \\
\hline Main Parachute Size & $85.5 \mathrm{ft}$ Do & $116.0 \mathrm{ft}$ Do & $94.0 \mathrm{ft} \mathrm{Do}$ \\
\hline Packed Volume & $3.18 \mathrm{ft}^{3}$ & $5.89 \mathrm{ft}^{3}$ & $3.77 \mathrm{ft}^{3}$ \\
\hline Pack density for flight & $42.7 \mathrm{lbm} / \mathrm{ft}^{3}$ & $47.0 \mathrm{lbm} / \mathrm{ft}^{3}$ & $38.9 \mathrm{lbm} / \mathrm{ft}^{3}$ \\
\hline Highest packing pressure & $300 \mathrm{psi}$ & $154 \mathrm{psi}$ & $57 \mathrm{psi}$ \\
\hline Longest soak time & $12 \mathrm{~h}$ at $226 \mathrm{psi}$ & $17 \mathrm{~h}$ at $114 \mathrm{psi}$ & $12 \mathrm{~h}$ at $26 \mathrm{psi}$ \\
\hline$\%$ of Solid Density & $59.8 \%$ & $57.5 \%$ & $49.3 \%$ \\
\hline
\end{tabular}

\begin{tabular}{|c|c|c|c|}
\hline Problem & Apollo Main & CPAS Main & Development Main \\
\hline Damage to reefing rings & Custom double ring & Textile reefing loops & Some cracked rings \\
\hline Small cuts and burns & Accepted risk & None Noted & None Noted \\
\hline Friction inside fixture & Teflon ${ }^{\circledR}$ impregnated liner & Teflon ${ }^{\circledR}$ cloth liner & Teflon ${ }^{\circledR}$ cloth liner \\
\hline
\end{tabular}

Figure 6 plots the maximum pressure used during packing against the final $\%$ of solid density achieved for the three wedge-shaped main parachute packs. Note the similarity to Figures 1 and 5, which are pressure vs. density curves for the Nylon and Kevlar ${ }^{\circledR}$ parachutes in cylindrical fixtures. This would indicate that pressure vs density curves will follow a similar shape, vertically shifted up or down on the y-axis by the packing fixture shape and material composition.

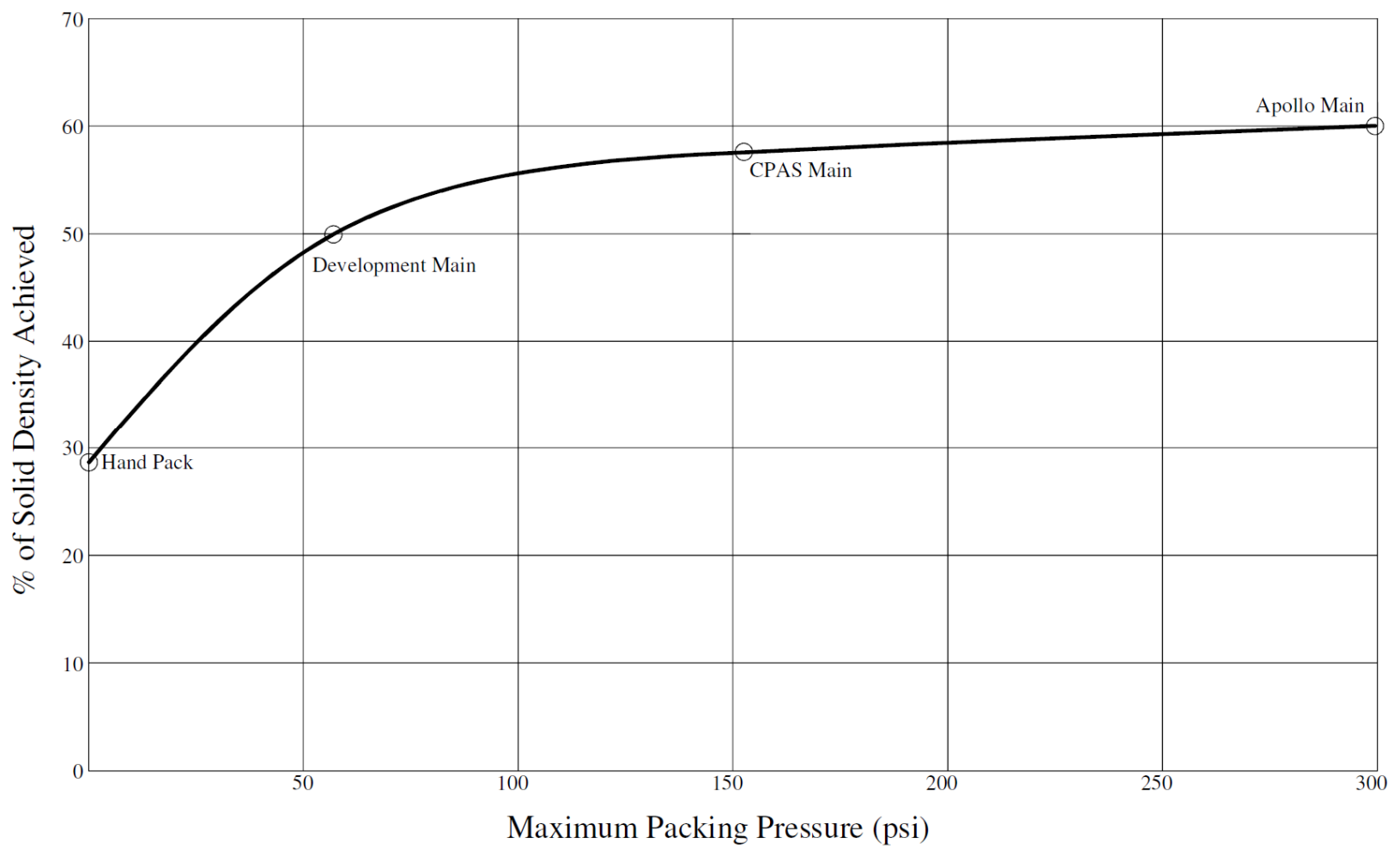

Figure 6. Packing Pressure vs \% of Solid Density for Wedge-Shaped Packs.

In place of using the total density as a benchmark for assessment of packing severity, calculating the weighted average solid densities of a group of packs allows an accurate comparison free from uncertainty caused by different mixes of materials. Evaluating density in this way adds a fourth variable to those usually examined for assessment of pack density.

1. The general shape of the fixture such as a cylinder, wedge, or box

2. Aspect ratio of the fixture (tall and narrow or short and wide) 
3. The implementation of reefing rings and cutters in the design

4. Mass fractions of materials, to calculate weighted average solid density

Using weighted average solid density will provide a future means of comparing old and new pack designs in order to duplicate or improve on past successes in volumetric efficiency of parachute stowage. By finding the percentage of solid density for a proposed packing scheme, it may be possible to predict the likelihood of damage to cutters and reefing rings before prototype fixture construction. This would serve to more accurately allocate space, mass, and engineering time for packing damage mitigation strategies such as reefing cutter sleeves, textile reefing loops, and padded cutter pockets.

The future of parachute technology will incorporate new materials with properties far different from today's textiles. Use of a non-dimensional means of pack density comparison will preserve the value of current benchmark designs for planning future projects with new materials, and for assessing the impact of material substitution in existing designs.

\section{Acknowledgments}

The authors would like to acknowledge Chuck Lowry who provided the Apollo information, first hand accounts of Apollo packing experience, and a constructive evaluation of the content of this paper.

\section{References}

${ }^{1}$ West, R. B.; “Apollo Experience Report - Earth Landing System”; NASA TN D-7437; November 1973

${ }^{2}$ Knacke, T.W.; "Study of Pressure Packing Techniques for Parachutes”; ASD-TR-61-426; September 1961

${ }^{3}$ Knacke T.W.; "The Apollo Parachute Landing System"; Presented to the2nd AIAA Aerodynamic Decelerator Systems Conference; El Centro, CA; September 1968

${ }^{4}$ Northrop Ventura; "Main Parachute Inspection and Packing Instructions (Increased Capability)"; NVR 6015E; April 1969

${ }^{5}$ Knacke, T.W.; “Apollo Spacecraft Earth Landing System (ELS) Experience and Data Collection”; 2659-5, Volume 1; August 1991

699-1536B, "EDU Main Parachute Packing Procedure”, Airborne Systems North America, February 2012

${ }^{7}$ Ewing, E.G., "Ringsail Parachute Design" AFFDL-TR-72-3, January 1972

${ }^{8}$ R-7661, “Parachute, Ringsail, 85.5' Do Conical (Block II)”, Northrop Ventura, September 1964

${ }^{9}$ R-8080, "Deployment Bag, Main Parachute", Northrop Ventura, August 1966

${ }^{10} 726162-503$ "CPAS EDU, Canopy, Ring Sail 116FT Do”, Airborne Systems North America, November 2012

${ }^{11} 779034-501$ "CPAS EDU Drogue, 23 ft Do VPCR, 24 Gore”, Airborne Systems North America, December 2012

${ }^{12} 708405-503$ "CPAS EDU Pilot Chute, 9.85 Do Conical Ribbon”, Airborne Systems North America, November 2012

${ }^{13} 708416-501$ "CPAS EDU FBC 7.0ft Do Conical Ribbon Parachute”, Airborne Systems North America, November 2012 